\title{
True Reason for Climate Change
}

\author{
Oleg Halidullin* \\ Kazakh National University, Kazakhstan \\ *Corresponding author: Oleg Halidullin, Independent Researcher, Almaty, Republic of Kazakhstan, Kazakhstan. \\ To Cite This Article: Oleg Halidullin. True Reason for Climate Change. Am J Biomed Sci \& Res. 2019 - 1(3). AJBSR.MS.ID.000524. \\ DOI: 10.34297/AJBSR.2019.01.000524
}

Received: January 29, 2019 | Published: February 14, 2019

\section{Commentary}

The US withdrawal from the Paris Agreement is the right move by President D. Trump. To sustain and enhance such a move, he needs an idea based on the true cause of climate change. The International Panel on Climate Change (IPCC) found greenhouse gases to be the culprit for climate destruction. Water vapor is a greenhouse gas.

Climate changes from the destruction of the water cycle between the atmosphere and the surface of the planet. The water circuit has been refined for millions of years. The last $100-200$ years, this mechanism began to deteriorate with the development of civilization. We turned water into a working reagent, changed its natural purpose. We destroy the structure of water in all technological processes where it is used. These are heating, boiling, cooling, hardening, drying, washing, pressure and many other operations. After each of them, the water evaporates immediately and after it is drained into the sewage system and septic tanks. Evaporation of such waters increases with the development of productivity and the creation of new technologies with increasing acceleration. In terms of volume, evaporation that is new and alien to nature exceeds $\mathrm{CO}_{2}$ emissions by 18,000 times. The improvement of industrialization in all spheres led to a reduction of 70 percent of the land area by arable land, reservoirs, deforestation, landfills, cities. From all these territories, the main part of the water evaporates without fulfilling its natural mission as it came from the sky, it went back. We produce even more artificial vapours in industry, agriculture and public utilities. We change the structure of water molecules contained in the air by millions of different mechanisms, especially the engines of the air, ship, and all other types of transport that take in the humidified air of clouds, nearwater and land surfaces. It should add here and all the other internal combustion engines, compressors, furnaces and heaters.

All new evaporations for nature, except for the new quality, are showing an increase in volumes and rates of return to the atmosphere. Every year we take away 22 million cubic kilometres of water from underground and surface sources. All this water instantly turns into steam, goes to the sewage system, septic tanks and again into the atmosphere. These three factors - quality, volume and rate of evaporation - created a new mechanism for the water cycle, which operates according to new, unnatural, incomprehensible laws. From here we get the answer of nature in the form of natural disasters, heavy rainfall with floods in some places, lack of moisture with fires in others, rising ocean levels, melting glaciers. It was the change in the geography of precipitation that led to the fact that heavy clouds do not reach the glaciers and overflow rivers and oceans. This explains the moisture and even flooding in the deserts of Africa, South America, Arabia.

To stop climate change means to save life on the planet, the future of our descendants and the whole biota. This is only possible by returning the nature of the natural functions of water. Development of a new water treatment concept is needed. Perhaps all is not lost, and the new mission is feasible for ours and the next subsequent generation. Otherwise there will be no other generations. Saving life on the planet requires an urgent release of water from work functions. It is necessary to reduce artificial evaporation. There are many different runaway types of water consumption that can be cut without much sacrifice. We must start with these expenses, we must begin now. The main elements of the new concept should be:

1. Complete reconstruction of the agricultural sector. Watering the channels and spray considered an anachronism. Drip irrigation and plow-free plowing have long been known in the world.

2. Prohibit the design and construction of dams for hydroelectric power plants and proceed to the production of all existing reservoirs. 280 hydroelectric power stations are being designed and built on Amazon. The same happens in Russia, China, Thailand.

3. Urgently prohibit landfills. This is created in the Scandinavian and other developed countries. Waste is given a second use. For example: https://ulicaekologiczna.pl/ 
przyjazne-srodowisku/kamikatsu-miasteczko-bez-koszysmieci - City without garbage

4. Prevent flooding by dredging the rivers. There are many inventions of the simplest and most effective ways of returning riverbeds to their historical state.

5. Move the infrastructure of cities under the ground. So the development of the metro has already led to retail space and other objects.
6. Cover existing building walls with plants. To create for this a new type of production of fruits and vegetables, reduce the area of agricultural land, reduce transportation costs. 